\title{
The Election of the Big 4 Audit Firms In Mexico an Empirical Analysis (2000-2007)
}

\author{
Juan Alfonso Toscano Moctezuma \\ Institute of Social Sciences and Management \\ Autonomous University of Ciudad Juarez \\ María Antonia García Benau \\ School of Economics, University of Valencia
}

\begin{abstract}
In this article, we present the results of an empirical study on the factors that determine the election of the Big 4 in Mexico during the period from 2000 to 2007. To this purpose, we have estimated a logistic regression model using a sample of companies listed on the Mexico Stock Exchange and its financial statements audited by an independent auditor. The results indicate that corporate features such as; the presence of controlling shareholders, the debt level, the presence of foreign investors, business size and requirement for additional services by audited companies are some of the factors determining the election of the Big 4 in Mexico.
\end{abstract}

KEYWORDS: Election, audit, quality, heterogeneous, Big 4 in Mexico.

\section{INTRODUCTION}

The international literature emphasizes that the election of an auditor with image and reputation (Barton, 2005; Beattie, 1989; Craswell et al, 1995; Fargher et al, 2001; Firth, 1990; Marten et al, 1998; Krishnamurthy et al, 2002; Moizer, 1997), is an issue that is related to the market structure (Zeff and Fossum, 1967), so the study on this issue becomes very relevant for accounting research especially for understanding the operation of the markets for financial audit services (DeAngelo, 1981; Kaplan et al, 1990).

The starting point of the empirical studies on the election of auditor considers that the concentrated structure of the audit market does not appear simply by an arbitrary decision process by the audited companies, but on the contrary, there are important economic reasons that explain the behavior of these companies to choose a specific auditor, specifically to choose one of the large international audit firms better known as the big 4 (Francis and Wilson, 1988; DeFond, 1992; Beatty and Fearnley, 1995).

In other words, the decision to selection a particular auditor by the companies, are the result of a rational process, whose explanatory variables have been subjected to a major international research literature in recent decades (Mock and Samet, 1982; Palmrose, 1984; Schroeder et al, 1986; Simunic and Stein, 1987; Balvers et al, 1988; Francis and Wilson, 1988; Beatty, 1989; Sutton and Lample, 1990; Menon and Williams, 1991; DeFond, 1992; Beatty and Fearnley, 1995; Hogan, 1997; García Benau et al, 2000).

In Mexico, the study of the audit market to date has only been analyzed from the point of view of the demand for the service. However, it is important to emphasize that the decision on the 
election of auditor belongs exclusively to the companies that demand the service, that is, the only decision to select a particular auditor is responsible only to the decision-making organs of the audited companies (Moizer at al, 1998; Aksu et al, 2007; Adams and Davis, 1994; GarciaBenau et al, 2004).

The structure of this paper is as follows. After this introduction, the second section is devoted to a review of the literature on the election of an auditor with image and reputation. The third section describes the empirical study, comprising the sample used, the formulation of hypotheses, the methodology and variables used. The fourth section presents the analysis of results of the empirical study. Finally, in the fifth section summarizes the main conclusions of this study.

\section{LITERATURE REVIEW}

The accounting research published in the international literature has a conceptually consistent argument and that over time it has been tested empirically in order to be able to demonstrate that concentrated audit market structure may come explained by the hypothesis of heterogeneity of service. According to this premise, companies that demand audit service offered perceive the different qualities, why those companies will elect those auditors who offer the level of quality required by them (Stein et al., 1994; Francis, 2004; Fuerman, 2005; Garcia-Benau et al, 1999).

The underlying argument to explain the existence of a heterogeneous demand for audit quality, explained in response to different situations, such as high agency costs, asymmetric information, etc., involving certain companies to deal with such situations they need a high quality audit, because this is a measure of the reliability of accounting figures, so selecting a high quality auditor means greater reliability of accounting information disclosed. For further information on this issue, attention should be paid to the auditing service attributes which make possible the heterogeneity of the same (Dopuch and Simunic, 1982; Francis and Wilson, 1988; DeFond, 1992; Albrecht and Willingham, 1993; Beattie and Fearnley, 1995; Craswell et al, 1995; Garcia-Benau et al, 1998; 2000).

Since the seminal work of DeAngelo (1981), it exists in the generally accepted accounting research on audit service, and that the quality of the auditor is an attribute that can be defined in terms of reputation, that is, the prestige gained for a given auditor indicates their level of professional quality. In this sense, the heterogeneity of service based on reputation, considers that there are strong incentives for auditing firms decide to specialize in providing a specific level of credibility when issuing an opinion, thus incurring significant fixed costs in building an image or a brand name that works as an objective indicator perceptible by third parties (Moizer, 1997; Nichols and Smith, 1983; Abbott and Susan, 2000; DeFond et al, 2002).

This argument is based on the auditors of these big auditing firms they are "outside the collective reputation they have as an organized profession 'individual reputation to maintain and create. Likewise, the literature has shown that the existence of reputation associated with the name brand is positively related to the ability of the Big 4 for high fees and attract new customers, that is, a reputation that is derived from the brand name becomes one of the key attributes for which audited companies choose and keep their auditors (Simunic and Stein, 1987; Craswell et al, 1995; DeFond et al., 2002, Ireland and Lennox, 2002; Fargher et al, 2001; Firth, 1990). 
In a market such as audit services, where there is strong information asymmetry between buyers and sellers and therefore an additional difficulty in assessing the quality of service provided, the brand name constitutes an essential attribute on which you can base the auditor heterogeneity (DeAngelo, 1981; Dopuch and Simunic, 1982; Palmrose, 1986; and Simunic and Stein, 1987; Financial Reporting Council, 2006).

In this regard, the international literature indicates that one of the indicators to reveal the differentiation in the quality of auditors in the audit market is to consider the existence of two groups of auditors in response to the brand name, distinguishing the Big 4 and those with a brand name, unlike the rest of the bidding firms in that market lacking a brand name (Simunic and Stein, 1987; Craswell et al, 1995; DeFond et al, 2002; and Ireland Lennox, 2002).

This argument is based on the auditors of these big auditing firms they are "outside the collective reputation they have as an organized profession 'individual reputation to maintain and create. Likewise, the literature has shown that the existence of reputation associated with the name brand is positively related to the ability of the Big 4 for high fees and attract new customers, that is, a reputation that is derived from the brand name becomes one of the key attributes for which audited companies choose and keep their auditors (Simunic and Stein, 1987; Craswell et al, 1995; DeFond et al, 2002, Ireland and Lennox, 2002; Garcia-Benau et al, 2004). So, if we look at the definition of widespread reputation for DeFond et al, (2002), as is the ability to gain new customers while existing retained, it then audit firms with the largest share the market will be the most reputable and therefore also be associated with a higher level of quality as auditors (Johnstone and Bedard, 2004; Knapp, 1991).

This is the reason that the largest auditing firms, that is, large international firms, better known as the Big 4 are considered in accounting research as the highest quality and reputation. Hire as a quality auditor according to the literature can provide significant advantages and is therefore not surprising that business managers consider the reputation as a key factor in the choice of auditor (GA0, 2003; Monterrey and Sanchez, 2008).

This means that the factors behind the select of a particular auditor acquire relevance indirectly to the extent that emphasize on what are the incentives audited companies to opt for the selection of the Big 4 (DeAngelo, 1981; Francis and Wilson, 1988; DeFond, 1992; Teoh and Wong, 1993; Beattie and Fearnley, 1995; Arruñada, 2000; Garcia-Benau et al, 2000; Tiesenhausen, 2004; Schloetzer, 2005).

In this article, we have presented so far theoretical arguments that accounting has been conducting research to justify conceptually concentrated audit market structure may come explained by the hypothesis of the audit service differentiation, thus concluding that the choice of a reputed auditor, is a determinant for certain companies requiring audit services above the minimum legally required quality, that gives credibility to financial statements that is perceived by third quality factor (Nichols and Smith, 1983).

In addition to the above, the accounting research also highlights through publications in international literature that offer differential quality, ie, the differential credibility, costs for the company that the claim or the contract, which means that there are powerful reasons for these companies select auditors offer higher quality service provision (Shroeder et al, 1986; Krishnamurthy et al, 2002; Thornton and Moore, 2006).

One reason that according to the literature justifies the selection of a one audit firm of the Big 4 , is because your reputation favors the credibility of accounting information, it reinforces 
investor confidence in the integrity of financial statements of companies to document higher coefficients in response to the result companies audited by the Big 4 (Nichols and Smith, 1983; Teoh and Wong, 1993). In their study on the selection of auditor in Spain (Garcia-Benau et al, 2000), the Spanish companies select their auditor considering his reputation it brings credibility perceptible by third parties to the accounting information the audited company.

A second helping to select a reputable auditor is that helps mitigate agency conflicts and reduce contract costs, and thus in companies with significant debt also monitors the debt (Arruñada, 2000; Lai and Yim, 2002; Onder et al, 2004; Pittman and Fortin, 2004; Clatworthy and Peel, 2007; Kealey et al, 2007; Landsman et al, 2008). In this regard, Hay and Davis (2004) analyzed whether the choice of auditor is conditioned by the level of indebtedness of the companies, the results show a significant relationship between that level and quality auditor, suggesting that demand for reputable auditors related to the desire to mitigate agency conflicts and provide credible information.

Since Jensen and Meckling (1976) argue that the financial audit is of particular relevance to control conflicts of agency companies, accounting research has been guiding the analysis of how the nature of these relationships, conflicts and agency costs that they can arise from the same can be explained differentiated demand of audit quality and therefore the selection of a particular auditor (Fama, 1980).

A third reason to select an auditor of quality is that their action could reduce the risk of information, understood as the probability that specific information from a company that is relevant to the decision of investors is low quality, which would adverse effects, for the reason that poor quality information will hurt the perception of investors, who will demand a higher risk premium. Thus, firms with higher risk of information as theoretical forecasts of Easley and O'Hara (2005) would have a higher cost of capital, as verified empirically Francis et al, (2005), Barton (2005) and Pittman and Fortin (2004). In this sense, Citron and Manalis (2001) in their empirical work on the election of auditor in Greece highlighted how the election of one of the Big 4 is related to the degree of participation of international investors in listed companies, which interpret in terms of providing credibility to the financial information. Finally, the accounting literature emphasizes that companies in need of advice tend to hire a large auditor, as this ensures greater coverage of services and additionally, reduced expenses for the company may assume that the auditor together determine the audit and consulting fees, if possible overlap joint costs (Pong and Whittington, 1994; Firth, 2002; Antle et al, 2004; Monterrey and Sanchez, 2008).

\section{Sample}

\section{EMPIRICAL STUDY}

To carry out our empirical study, the sample used was determined by the set of Mexican nonfinancial companies listed on the Mexico Stock Exchange, with these business concerns that the New Stock Market Law (DOF Mexico 2005) is required to submit their annual financial statements audited by an independent auditor. Data from this study concern understood period from 2000 to 2007. The total of observations are based on an initial sample of 972 companies-year, of which 860 observations have discarded because companies in these cases decided to maintain the current auditor for following financial year, then leaving a final sample of 112 companies-year corresponding to events where companies selected an auditor during the study period. The summary data of the sample is shown in Table 1, below: 
Table 1. Description of the Sample

\begin{tabular}{|l|c|c|c|c|c|c|c|c|c|}
\hline \multicolumn{1}{|c|}{ Sample } & 2000 & 2001 & 2002 & 2003 & 2004 & 2005 & 2006 & 2007 & Total \\
\hline Total of observations & 108 & 113 & 117 & 120 & 124 & 134 & 131 & 125 & 972 \\
\hline Auditor maintenance & 101 & 104 & 90 & 98 & 107 & 121 & 121 & 118 & 860 \\
\hline $\begin{array}{l}\text { Total Auditor } \\
\text { Election }\end{array}$ & 7 & 9 & 27 & 22 & 17 & 13 & 10 & 7 & 112 \\
\hline
\end{tabular}

As can be seen in Table 1, the total of 972 observations that make up our sample, only 112 correspond to election auditor by companies audited during the period from 2000 to 2007. In Table 6.2, the following described settings our final sample type selected auditor, as follows:

Table 2. Number of auditor elections in Mexico

\begin{tabular}{|c|c|c|c|c|}
\hline Firm & $\begin{array}{c}\text { Election of } \\
\text { auditor for the } \\
\text { first time }\end{array}$ & $\begin{array}{c}\text { Election of } \\
\text { auditor after a } \\
\text { change }\end{array}$ & $\begin{array}{c}\text { Total } \\
\text { Election } \\
\text { of Auditor }\end{array}$ & $\begin{array}{c}\text { Percentage } \\
\text { Elections }\end{array}$ \\
\hline Big 4 & 8 & 78 & 86 & $76,8 \%$ \\
\hline No Big 4 & 5 & 21 & 26 & $23,2 \%$ \\
\hline $\begin{array}{c}\text { Total } \\
\text { Elections }\end{array}$ & 13 & 99 & 112 & $100 \%$ \\
\hline
\end{tabular}

In the Table 2, we can see that of the 112 elections of auditor, we observed 86 events companies, who they decided to hire as its auditor to one of the Big 4 what It represents 76.8\% of the total sample. These data are consistent with results obtained by other previous empirical studies that have shown the high concentration of the audit market in Mexico by the control of the Big 4.

\section{Hypothesis}

Choosing a reputable auditor for companies, could mitigate conflicts of agency companies, by encouraging a perception of credibility of accounting information (Monterrey and Sanchez, 2008). Since, Jensen and Meckling (1976) argue that the financial audit is of particular relevance to control conflicts of agency companies, accounting research is aimed at analyzing how the nature of these relationships, conflicts and agency costs that they can arise from the same may explain a heterogeneous demand for audit quality and therefore the selection of a particular auditor (Dopuch, 1984; Watts and Zimmerman, 1983; Whisenant and Sankaraguruswamy, 2000; Piot, 2001).

It is for this reason that the first hypothesis that we will submit to contrast our investigation related to the effect that the level of share ownership may result in the election of the auditor. 
According to Shleifer and Vishny (1986) show that the holders of significant blocks of shares audit quality demand as an additional guarantee of reliability of accounting information of the company. The presence of these majority shareholders in the boards and not exhaust the list of the complete monitoring of senior management and the renowned auditor in these cases can play a complementary to the controlling shareholders role as limiting mechanism agency costs, monitoring managers with weak equity ownership in the company. Accordingly, the first hypothesis is as follows:

H1: The companies with presence of controlling shareholders have more incentive to select one of the Big 4.

Also, companies in which the assets are financed by debt, the agency conflicts may arise from the financial creditors to shareholders of the company. In this regard, Simunic and Stein (1987) and Francis and Wilson (1988) found in their empirical studies a negative association between the level of debt of the audited company and the selection of an auditing firm of the Big 4 . The reason according these researchers, it could be that large audit firms may be avoiding the review of companies with a high level of financial leverage due to higher risk in relation to the audit. Thus, the second hypothesis is as follows:

H2: The companies with less debt have greater incentives to hire a firm of the Big 4 .

As for agency conflicts and credibility of financial information, according to the accounting researchers Citron and Taffler (1992) and Citron and Manalis (2001) are based on the assumption that companies with foreign investors may be largely influenced hiring one of the big 4. This is because these big auditing firms are considered most highly by users of accounting information, especially for foreign investors. Therefore, in the third scenario we expect a positive association between the presence of foreign companies and investors the election of the Big 4, as follows:

H3: Companies with the presence of foreign investors have greater incentives to choose a firm of the Big 4.

Continuing our analysis, we must also emphasize that according to accounting researchers Chow (1982), and Bar-Yosef Livnat (1984), Johnson and Lys (1990), Simunic and Stein (1987), Francis and Wilson (1988), Firth and Smith (1992), Abbott and Parker (2000), Gietzmann and Senn (2002) and Barton (2005) in their studies indicate that the larger audited companies can receive a higher quality of service by the Big 4. It why for our fourth hypothesis a positive association between the size of the audited companies and the selection of a quality auditor is expected as follows:

H4: Large companies have greater incentives to select one of the Big 4 firm.

As regards the fifth and final hypothesis to be considered in our empirical study, it is worth noting that researchers Firth (2002), Antle et al, (2004) and Barton (2005), in their studies show that companies with counseling needs tend to hire an auditor large as this to ensure better coverage of additional services (Firth, 1997). So, then, we expect a positive relationship between the hiring of additional services by audited companies and the selection of a reputable auditor, as follows: 
H5: Companies that hire additional services have greater incentives to choose a firm of the Big 4.

Finally, our empirical study as control variables include the sectors of economic activity of enterprises based on the classification that the Mexican Stock Exchange has made in this regard: (1) Trade (2) Communications and Transport (3) Building (4) Mining and quarrying, (5) Services (6) Processing and (7) Various. In this regard, Willekens et al., (2004) indicate that it is necessary to monitor the effects of the economic sectors of business and conflicts of agency may differ among themselves, waiting for both a positive association between the economic sector and the selection a reputable auditor. So then, the contrast of the stated hypothesis is carried out through the following linear regression model:

\section{Methodology and variables used}

For the testing of hypotheses (Anderson et al, 1996) and to analyze the factors of selection the Big 4 in Mexico, we will estimate the following logistic regression model:

\section{ELAUDi $=\beta 0+\beta 1 A C C S P P L S+\beta 2 E N D E U D+\beta 3 I N V E X T R+\beta 4 L O G A C T+\beta 5 S E R V A D+$ $\Sigma \beta$ ISECTORi $+i$}

Where, the dependent variable ELAUD is a dummy variable that has a value of 1 if the auditor selected by the companies in the sample belongs to the Big 4 (Deloitte Touche Tohmatsu, KPMG, Ernst \& Young, and PriceWaterhouseCoopers) and a value equal to 0 otherwise. And where, the independent variables are the factors that collect choosing the Big 4 from the point of view of the audited companies, are:

a) Major Shareholders: As an approximation of the companies audited presence of controlling shareholders, we have defined the first explanatory variable ACCSPPLS, which was measured by the percentage of shares of the capital of audited companies held by the main internal stakeholders (Vafeas, 1999, Bédard et al, 2004).

b) Debt: The second explanatory variable ENDEUD is referred to the debt of the audited companies, as the ratio of total liabilities and total assets of the company at book value at year end (Eichenseher and Shields, 1989; DeFond 1992; Firth and Smith, 1992; Abbott and Parker, 2000).

c) Foreign investors: As an approximation of foreign investors in companies, defined INVEXTR third explanatory variable, dummy variable that takes value 1 if the company exists in the presence of foreign investors with shareholding, and 0 otherwise (Citron and Manalis, 2001).

d) Size: As for the amount of the fourth explanatory variable LOGACT measure represents the size of the audited company and is defined by the natural logarithm of the total assets of the company at year end. In this respect the literature contains several studies through which it has been used as the surrogate of Palmrose (1984), Francis and Wilson (1988), Williams (1988) and Eichenseher and Shields (1989).

e) Additional services: As an approximation of the additional services hired by companies defined SERVAD fifth explanatory variable, dummy variable that takes value 1 if the company besides hiring audit services, additionally also contracts with same auditor selected, additional professional services, such as; consulting, tax advice, legal advice, etc., and take the value of 0 otherwise.

f) Sector: Finally as a proxy for economic activity sector of the company have defined seven dummy variables control. The sectors are: trade (COM), communications and transport (CYT), construction (CONSTR), extractive industry (INDEXTR), services 
(SERV), processing (TRANS), and several (VAR). In all cases it takes the value 1 if the company belongs to the selected area and 0 otherwise.

It is important to note that the financial and corporate information used to measure the independent variables was obtained through the analysis of annual reports of listed companies that are registered in the database published on the website of the Mexican Stock Values.

\section{Univariate Statistical Analysis}

\section{EMPIRICAL RESULTS}

Before turning to the hypotheses, Table 3, a univariate statistical analysis of the mean difference between the total sample segmenting companies audited by the Big 4 and other companies audited by other auditing firms is presented included. For this purpose, we have verified whether there are significant differences between the behaviors of both samples using therefore the nonparametric test of Mann-Whitney test for continuous variables and the chisquare test for categorical dichotomous variables.

Table 3. Univariate Analysis Half of Differences

\begin{tabular}{|c|c|c|c|c|}
\hline Variables & $\begin{array}{c}\text { Companies } \\
\text { audited by The } \\
\text { BIG } 4^{*} \\
(\mathrm{~N}=86)\end{array}$ & $\begin{array}{l}\text { Companies not } \\
\text { audited by the BIG } \\
\begin{array}{c}4 \\
(\mathrm{~N}=26)\end{array}\end{array}$ & $\begin{array}{l}\text { Statistical } \\
\text { average } \\
\text { differences }\end{array}$ & $\begin{array}{c}\text { Univariate } \\
\text { Statistical Test } \\
\text { (Significance } \\
\text { level.) }\end{array}$ \\
\hline ACCSPPLS & .8142 & .6762 & 0.13803 & $627.5(\mathrm{p}=0.001)^{*}$ \\
\hline ENDEUD & .5469 & 6158 & -0.06891 & $\begin{array}{c}1008.5 \\
(p=0.450)\end{array}$ \\
\hline LOGACT & 15.8008 & 14.4438 & 1.35697 & $626.0(\mathrm{p}=0.001)^{*}$ \\
\hline INVEXTR & .49 & .04 & .45 & $6.036(\mathrm{p}=0.014)^{*}$ \\
\hline SERVAD & .51 & .12 & .39 & $2.893(p=0.089)$ \\
\hline $\mathrm{COM}$ & .14 & .23 & -.09 & $\begin{array}{c}51.571 \\
(p=0.000)^{*}\end{array}$ \\
\hline CYT & .08 & .19 & -.11 & $\begin{array}{c}69.143 \\
(p=0.000)^{*}\end{array}$ \\
\hline CONSTR & .10 & .12 & -.02 & $\begin{array}{c}69.143 \\
(p=0.000)^{*}\end{array}$ \\
\hline INDEXTR & .08 & .00 & .08 & $\begin{array}{c}87.750 \\
(p=0.000)^{*}\end{array}$ \\
\hline SERV & .15 & .04 & .11 & $\begin{array}{c}63.000 \\
(p=0.000)^{*}\end{array}$ \\
\hline TRANSF & .36 & .42 & -.06 & $7.000(\mathrm{p}=0.008)^{*}$ \\
\hline VAR & .13 & .00 & .13 & $\begin{array}{c}72.321 \\
(p=0.000)^{*}\end{array}$ \\
\hline
\end{tabular}

According to data compiled in Table 3, it can be seen in terms of quantitative independent variables, that both ACCSPPLS "representative of the percentage of shares to major shareholders of the company" variable, as LOGACT variable 'representative size company measured by the logarithm of total assets, "show a statistically different behavior, ie, the mean difference of these two variables are significantly different between the companies audited by the Big 4 and the companies audited by other auditing firms the level of significance of $5 \%$. 
We also note according to the data in Table 3, these variables show the expected values, ie, the companies in the sample that select to the Big 4 as its independent auditor show a higher percentage of shares capital in favor of major shareholders and which are the largest in terms of company size.

By contrast, in Table 3, we note that the ENDEUD "representative of the level of indebtedness of the audited company 'variable univariate level does not show a statistically significant difference at the $5 \%$ averages.

As for the mean values of debt, it shows that the level of debt of the companies audited by the Big 4 is less about the level of indebtedness of the companies that were audited by other audit firms.

Moreover, in relation to categorical independent variables, we see in Table 3, the INVEXTR "representative of the presence of foreign investors in the audited company 'variable univariate level shows a different behavior, ie the mean difference is significantly different from companies that select to the Big 4 and companies that select the rest of the other auditing firms, 5\% significance level.

We also note that this independent variable if it shows the expected values, ie, the presence of foreign investors is higher in Mexican companies selected as its external auditor to the Big 4 that choose to rest other auditing firms as its independent external auditor.

Relating to the SERVAD "representative of the presence of additional services contracted by the auditor selected by the audited company 'Variable see in Table 3 that the mean differences are not significant at the $5 \%$ level of significance, even if shows expected values, ie companies that are audited by the Big 4 are those most frequently hired additional services to their auditors in turn respect of companies are audited by other audit firms.

Finally, as to the variables corresponding to the sectors of the audited companies control observed in Table 3, the mean differences for these variables are statistically significant at the $5 \%$ level of significance, but as expected values, these show mixed results.

Following the univariate statistical analysis and for purposes of assessing whether there is multicollinearity between the independent variables, since the number of observations in the sample used for the testing of hypotheses is quite small, in Table 4, below we have calculated the correlation coefficients Spearman of the independent variables. Thus, we believe that we can analyze with a better perspective the results of the proposed estimation logistic regression model we report.

From the results presented in Table 4 it shows that the correlation between pairs of all independent variables are minor, since none of the Spearman correlation coefficient is high enough ( $>0.60$ ) as to cause major problems multicollinearity, considering also that the goal of our proposed model is to identify the determinants of selection of the Big 4 but assuming there are variables that are interrelated to one another and not in isolation (Citron and Manalis, 2001; Pittman and Fortin, 2004; Anderson et al, 1996). 
Table 4. Spearman Correlations between the variables that explain the model

\begin{tabular}{|c|c|c|c|c|c|c|c|c|c|c|c|c|}
\hline $\begin{array}{l}\circ \\
\text { Variables } \\
\circ\end{array}$ & $\begin{array}{l}\text { ACCS } \\
\text { PPLS }\end{array}$ & \begin{tabular}{|cc} 
& \\
& END \\
0 & EU \\
&
\end{tabular} & $\begin{array}{l}\text { O } \\
\text { INV } \\
\text { EXTR }\end{array}$ & \begin{tabular}{|l} 
OOG \\
LCT \\
ACT
\end{tabular} & $\begin{array}{c}\text { SERV } \\
\text { AD }\end{array}$ & o & $\begin{array}{ll} & \\
& \text { CYT } \\
\end{array}$ & $\begin{array}{c} \\
\text { CONS } \\
\text { TR }\end{array}$ & \begin{tabular}{|c} 
O \\
IND \\
EXTR
\end{tabular} & S SERV & \begin{tabular}{|l}
0 \\
$\quad$ TRA \\
NSF
\end{tabular} & $\begin{array}{c}\text { VA } \\
\text { R }\end{array}$ \\
\hline $\begin{array}{ll}0 & \text { ACCS } \\
0 & \text { PPLS } \\
\end{array}$ & 1 & 0 & 0 & 0 & 0 & 0 & 0 & o & $\circ$ & 0 & 0 & \\
\hline $\begin{array}{l}\circ \\
\text { ENDEU }\end{array}$ & .103 & o $\quad 1$ & 0 & 0 & o & o & 0 & o & $\circ$ & 0 & 0 & \\
\hline $\begin{array}{l}\circ \\
\text { INVEXTR }\end{array}$ & 032, & .084 & o $\quad 1$ & $\circ$ & 0 & 0 & 0 & 0 & 0 & 0 & 0 & \\
\hline$\stackrel{\circ}{\text { LOGACT }}$ & .139 & $.189^{*}$ & $.198^{*}$ & 1 & 0 & 0 & 0 & o & 0 & 0 & 0 & \\
\hline$\stackrel{\circ}{\text { SERVAD }}$ & .144 & .082 & .110 & $.245^{* *}$ & 1 & 0 & 0 & 0 & $\circ$ & 0 & $\circ$ & \\
\hline ○ $\quad$ COM & -.074 & .027 & -.145 & $-.221 *$ & -.077 & 1 & 0 & o & $\circ$ & 0 & 0 & \\
\hline${ }^{\circ} \mathrm{CYT}$ & -.044 & .133 & .083 & .185 & -.002 & -.152 & 1 & 0 & $\circ$ & $\circ$ & 0 & \\
\hline $\begin{array}{l}\circ \\
\text { CONSTR }\end{array}$ & -.108 & -.022 & .023 & $-.187^{*}$ & -.119 & -.152 & -.120 & p $\quad 1$ & 0 & 0 & 0 & \\
\hline $\begin{array}{l}\circ \\
\text { INDEXTR }\end{array}$ & .141 & $.191^{*}$ & -.128 & $.310^{* *}$ & $.229^{*}$ & -.113 & -.089 & -.089 & o & 0 & 0 & \\
\hline $0^{\circ}$ SERV & .005 & -.205 & $.201^{*}$ & -.068 & .116 & -.092 & -.131 & -.131 & -.098 & 0 & 0 & \\
\hline $\begin{array}{l}\circ \\
\text { TRANSF }\end{array}$ & .071 & -.167 & -.005 & -.124 & -.061 & $-.339^{* *}$ & $-.268^{* *}$ & $-.268^{* *}$ & $-.200^{*}$ & -.181 & 1 & \\
\hline$\circ^{\circ}$ VAR & -.042 & .180 & .048 & $.335^{* *}$ & .023 &,-144 & -.114 & -.114 & -.085 & -.034 & $-.256^{* *}$ & 1 \\
\hline
\end{tabular}

The correlation is significant at the 0.01 level (bilateral). * The correlation is significant at the 0.05 level (bilateral) $\mathrm{N}=112$

\section{Multivariate Statistical Analysis}

Having analyzed the univariate results and to analyze how they work together all the variables proposed to effect the testing of hypotheses, first we proceeded to estimate the logistic regression model described above. Table 5 presents the results obtained:

In Table 5, the results of the logistic regression model 1 «which includes all variables proposals" and which was initially built to identify factors that explain the election of auditor by Mexican companies presented sample. So, you can see the result provided by the chi-square test, which shows how well the model generally reaching a value of 60.173 (6 degrees of freedom), so the null hypothesis absence of statistical relationship can be rejected. Also, we see in Table 5, the value reached by the Pseudo $\mathrm{R}^{2}$ is $62.8 \%$, indicating that the explanatory power of the model is high enough to be acceptable. The correct classification rate is $76.8 \%$ of the observations and the realization of the Hosmer and Lemeshow has revealed that there are no statistical differences between the estimated values and actual values (Chi-square $=6.189 ; \mathrm{p}=$ 0.628). So, the results of the logistic regression model obtained for 1 reveals the goodness of adjustment. 
Table 5. Results of the logistic regression of the model proposed

\begin{tabular}{|c|c|c|c|c|}
\hline \multirow[t]{2}{*}{ Variables } & \multirow[t]{2}{*}{$\begin{array}{l}\text { Expected } \\
\text { Sign }\end{array}$} & \multicolumn{3}{|c|}{$\begin{array}{c}\text { Model } 1 \\
\text { (with all the variables proposed ) } \\
\text { ELAUDi }=\beta 0+\beta 1 \text { ACCSPPLS }+\beta 2 \text { ENDEUD }+ \\
\beta \text { 3INVEXTR }+\beta \text { LLOGACT }+\beta \text { SSERVAD }+\sum \beta \text { iSECTOR } i+ \\
i\end{array}$} \\
\hline & & $\begin{array}{l}\text { Coefficient } \\
\text { model }\end{array}$ & Wald Test & $\begin{array}{c}\text { Level of Statistical } \\
\text { Significance }\left({ }^{*}\right)\end{array}$ \\
\hline Constant & & -2.958 & .696 & .404 \\
\hline ACCSPPLS & + & 7.332 & 10.903 & $.001^{*}$ \\
\hline ENDEU & - & -4.598 & 6.999 & $.008^{*}$ \\
\hline INVEXTR & + & -4.347 & 11.410 & $.001^{*}$ \\
\hline LOGACT & + & 0.429 & 3.936 & $.047^{*}$ \\
\hline SERVAD & + & -2.287 & 6.936 & $.008^{*}$ \\
\hline $\mathrm{COM}$ & + & -0.053 & 0.005 & .943 \\
\hline CYT & + & 2.237 & 3.993 & $.046^{*}$ \\
\hline CONSTR & + & -1.002 & 0.730 & .393 \\
\hline INDEXTR & + & -18.788 & 0.000 & .999 \\
\hline SERV & + & 0.365 & 0.068 & .795 \\
\hline TRANSF & + & 0.161 & 0.047 & .829 \\
\hline VAR & + & -19.560 & 0.000 & .999 \\
\hline $\begin{array}{l}\text { Chi- } \\
\text { Pse } \\
\text { Per }\end{array}$ & $\begin{array}{l}\text { quare }=6 \\
\text { do } R^{2}=0.6 \\
\text { ntage of } c\end{array}$ & $\begin{array}{l}73(p=0.000) 6 \\
8 \\
\text { rect classificatio }\end{array}$ & & \\
\hline
\end{tabular}

With respect to the explanatory variables ACCSPPLS, INVEXTR and LOGACT, the results obtained in the estimation of model 1 are consistent with those obtained in the univariate analysis were statistically significant all coefficients of these explanatory and with the expected signs variables. As for ENDEU and SERVAD variables, the results of the estimation of model 1 are different from the ones we found univariate level, because these two variables multivariate level show a statistically significant behavior, however univariate level were quite the opposite. With regard to expected for signs SERVAD ENDEU variables and the results of model 1 they are consistent with those at the univariate level.

Finally, with respect to the control variables, only the CYT variable has a statistical significance and with the expected sign. Contrary to the results obtained in the univariate analysis when all the control variables were statistically significant and the expected signs. Because the logistic regression model estimation 1 contained all the independent variables, and in order to determine the most parsimonious model, ie the model that offers the most robust results that allow us to explain the concentrated market structure audit Mexico, from the point of view of the audited companies, and in particular on some of the determinants of the choice of the Big 4 in Mexico, have again returned the sample data but now using only six explanatory variables in Model 1 above were statistically significant. The results of logistic regression of model 2 are shown in Table 6. 
Table 6. Results of the logistic regression model that explains the election of the BIG 4 audit firms in Mexico

\begin{tabular}{|c|c|c|c|c|}
\hline \multirow[t]{2}{*}{ Variables } & \multirow{2}{*}{$\begin{array}{l}\text { Expected } \\
\text { Sign }\end{array}$} & \multicolumn{3}{|c|}{$\begin{array}{c}\text { Modelo } 2 \\
\text { ELAUD } i= \\
(\text { with resulting significant variables in model } 1) \\
\beta 4+\beta \text { LOGACT }+\beta 5 \text { SERVAD }+\sum \beta i \text { CYT } i+i\end{array}$} \\
\hline & & $\begin{array}{l}\text { Coefficient } \\
\text { Model }\end{array}$ & Wald Test & $\begin{array}{l}\text { Level of Statistical } \\
\text { Significance }\left(^{*}\right)\end{array}$ \\
\hline Constante & & -6.875 & 2.695 & .101 \\
\hline ACCSPPLS & + & 7.313 & 10.588 & $.001^{*}$ \\
\hline ENDEU & - & -4.226 & 4.753 & $.029 *$ \\
\hline INVEXTR & + & -4.266 & 11.101 & $.001^{*}$ \\
\hline LOGACT & + & 0.545 & 4.807 & $.028 *$ \\
\hline SERVAD & + & -2.376 & 6.429 & $.011^{*}$ \\
\hline CYT & + & 2.237 & 3.993 & $.046^{*}$ \\
\hline $\begin{array}{l}\mathrm{C} \\
\mathrm{P} \\
\mathrm{P}\end{array}$ & $\begin{array}{l}\text { quare }=6 \\
\text { do } \mathrm{R}^{2}=0 \\
\text { entage of }\end{array}$ & $\begin{array}{l}574(\mathrm{p}=0,000) 6 \\
2 \\
\text { rect classificatic }\end{array}$ & & \\
\hline
\end{tabular}

For the data in Table 6, it appears that Model 2 is statistically significant, while offering a slightly greater explanatory power than the model 1 above as indicated by $66.2 \%$ of Pseudo $\mathrm{R}^{2}$ as measure of the model fit. Therefore, these results confirm the validity of the explanatory variables that were statistically significant in the model 1 above. Also, it can be seen in Table 6 , the Chi-Square statistical model 2 reaches a value of 64.574 ( 6 degrees of freedom), meaning that the null hypothesis of the absence of statistical relationship can be rejected. Another measure of the goodness of fit is determined by the percentage of correct classification provided by the estimated model to model 2 represented by $87.5 \%$ of the observations compared with $76.8 \%$ in the previous model 1 . Also, the realization of the Hosmer and Lemeshow has revealed that there are no statistical differences between the estimated values and actual values (Chi-square $=2.540 ; \mathrm{p}=0.960$ ).

With respect to the meaning of the coefficients or estimated variable parameters in the model 2 , we see in Table 6 that all coefficients were the expected sign, except for the INVEXTR and SERVAD variables. However, these two variables as the other variables included in the model 2 , all of them without exception, were statistically significant, as well as show the statistics obtained Wald, all high, prominent among them those related to variables INVEXTR and ACCSPPLS with the highest coefficients Wald $=11.101$ and 10.588 respectively. So then, we see in Table 6, all variables included in the model 2 have been statistically significant $(\mathrm{p} \leq 0.05)$. Based on the results obtained in this model 2, we can confirm about the explanatory power of all the variables included in the multivariate level it to.

This means that:

a) The companies audited in Mexico whose capital is highly concentrated in favor of domestic major shareholders "investors with a significant stake" have more statistical probability to select a one of the Big 4 audit firms. 
b) The companies audited in Mexico with lower levels of debt are more statistical probability to select a one of Big 4 audit firms.

c) The companies audited in Mexico with presence of foreign investors have more statistical probability and more incentive to select a one of the Big 4 audit firms.

d) The companies audited in Mexico that have a large business size, are more statistical probability to select a one of the Big 4 audit firms.

e) The companies audited in Mexico that require additional services are more statistical probability to select a one of the Big 4 audit firms.

f) The companies audited in Mexico whose economic activity belongs to the communications and transport sector as classified by the Mexican Stock Exchange are more statistical probability to select a one of the Big 4 audit firms.

Finally, it is important to highlight the potential limitations that may exhibit this empirical work. First, consider that the results should be interpreted with caution, since it is possible that they had omitted some variables that could better explain the model 2 . Second, the sample size used in this study could be more reduced than can be obtained in the future.

\section{CONCLUSIONS}

In this article, we have presented an empirical study analyzing the determinants of the selection of the Big 4 in Mexico for the period from 2000 to 2007.

Based on the results our empirical study, we can say that the election of the Big 4 in Mexico, is associated with some corporate features of audited companies such as; the presence of internal controlling shareholders, the debt level, the presence of foreign investors, business size, the requirement of additional services and the requirement of specialization in the field of communications and transport.

Therefore, we can conclude that the model that offers the most robust empirical results on some of the determinants of the selection of the Big 4 in Mexico for the period from 2000 to 2007, from the point of view of businesses it audited, it is as follows:

\section{ELAUDi $=-6.875+7.313$ ACCSPPLS + (-4.226) ENDEUD + (-4.266) INVEXTR + LOGACT + (-2.376) SERVAD + 2.237CYTi + i}

Where the election of the Big 4 in Mexico by the audited companies, is conditioned by some corporate characteristics of the companies audited are the determining factors such as; the presence of major controlling shareholders, the level of debt, the presence of foreign investors, business size, the requirement for additional services and expertise of the auditor in the field of communications and transport.

\section{Bibliografic References}

ABBOTT, L. Y PARKER, and S. (2000): “Auditor selection and audit comittee characteristics”, Auditing: A Journal of Practice and Theory, Vol. 19 (2), pp. 47-66.

ABBOT, L.J. Y SUSAN, P. (2000): “Auditor selection and audit committe characteristics”. Auditing: A Journal of Practice and Theory Fall, pp. 47-67.

ADDAMS, H. Y DAVIS, B. (1994): "Privately held companies report reasons for selecting and switching auditors", CPA Journal, Vol. 64 (8), pp. 38-41.

AGRAWAL, A. Y KNOEBER, C. (1996): “Firm performance and mechanisms to control agency problems between managers and shareholders”, Journal of Financial and Quantitative Analysis, Vol. 31 (3), pp. 377-397. 
ALBRECHT, W. Y WILLINGHAM, J. (1993): An evaluation of SAS No. 53, the auditor's responsability to detect and report errors and irregularities. The Expectation Gap Standards: Progress, implementation issues, research oportunities, New York: American Institute of Certified Public Accountants (AICPA).

AKSU, M.; ONDER, T. Y SAATCIOGLU, K. (2007): "Auditor Selection, Client Firm Characteristics, and Corporate Governance: Evidence from an Emerging", Working Paper available at Faculty of Management Sabanci University, pp. 1-44.

ANDERSON, D.; SWEENEY, D. Y WILLIAMS, T. (1996): Statistics for Business and Economics, 6th edition, West Publishing Co.

ANTLE, R.; GORDON, E.A.; NARAYANAMORTHY, G. Y ZHOU, L. (2004): “The joint determination of audit fees, nonaudit fees, and abnormal accruals", working paper, Yale University.

ARRUÑADA, B. (2000): “Audit quality: Attributes, private safeguards and the role of regulation”, The European Accounting Review, 9, pp. 205-224.

BALVERS, R. J.; MCDONALD, B.; Y MILLER, R. E. (1988): “Underpricing of new issues and the choice of auditor as a signal of investment banker reputation", The Accounting Review, 58(4), pp. 605-622.

BARTON, J. (2005): “Who Cares About Auditor Reputation?” Contemporary Accounting Research, 22(3), pp. 549586.

BAR-YOSEF, S. Y LIVNAT, J. (1984): “Auditor selection: An incentive-signaling approach", Accounting and Business Research, Vol. 14(56), pp. 301-309.

BEATTIE, R. (1989): “Auditor Reputation and the Pricing of Initial Public Offerings", the Accounting Review, No. 4, p. 693-707.

BEATTIE, V. Y FEARNLEY, S. (1995): “The importance of audit firm characteristics and the drivers of auditor change in UK listed companies", Accounting and Business Research, 25, Invierno, pp. 227-239.

BÉDARD, J; CHTOUROU, S.M. Y COURTEAU, L. (2004): "The effect of Audit Committee expertise, independence, and activity on aggressive earnings management, Auditing: A Journal of Practice \& Theory, 23, pp. 13-35.

CHOW, C. W. (1982): “The demand for external auditing: Size, debt and ownership influences". The Accounting Review, Abril, pp. 272-291.

CITRON, D. B. Y TAFFLER, R. J. (1992): “The audit report under going concern uncertainties: an empirical analysis", Accounting and Business Research, Vol. 22, No. 88, pp. 337-345.

CITRON, D.B. Y MANALIS, G. (2001): “The International audit firms as new entrants to the statutory audit market:: an empirical analysis of auditor selection in Greece, 1993-1997", European Accounting Review, Vol. 10(3), pp. 439-459.

CLATWORTHY, M. Y PEEL, M. (2007): "The effect of corporate status on external audit fees: evidence from the UK", Journal of Business Finance \& Accounting, 34(1\&2), pp. 169-201.

CRASWELL, A. T.; FRANCIS, J.R. Y TAYLOR S. L. (1995): "Auditor Brand Name Reputations and Industry Specializations", Journal of Accounting and Economics, pp. 297-322.

DEANGELO, L. (1981): “Auditor Size and Audit Quality”, Journal of Accounting \& Economics, 3, pp. 183-199.

DEFOND, E. M. (1992): “The Association Between Change in Client Firm Agency Costs and Auditor Switching”, Auditing: A Journal of Practice \& Theory, Vol. 11, No. 1, p. 16-31.

DEFOND, M. L.; RAGHUNANDAN, K. Y SUBRAMANYAM, K. R. (2002): “Do non-audit service fees impair auditor independence? Evidence from going concern audit opinions" Journal of Accounting Research, 40, pp. 1.247-1.274.

DOF MÉXICO (2005): Nueva Ley del Mercado de Valores, publicada el 30 de diciembre de 2005 en el Diario Oficial de la Federación (DOF) en México.

DOPUCH, N. (1984): "The demand for quality-differentiated audit services in an agency cost setting: An empirical investigation: Discussion, Auditing Research Symposium, University Urbana, pp. 253-263.

DOPUCH, N. Y SIMUNIC, D. (1982): “Competition in Auditing: An Assesment”, Fourth Auditing Research Symposium, University of Illinois, Champaign, IL. 
EASLEY, D. Y O'HARA, M. (2005): “Information and the cost of capital”, Journal of Finance, 59, pp. 1.553-1.583.

EICHENSEHER, J.; HAGIGI, M. Y SHIELDS, D. (1989): “Market reaction to auditor changes by OTC companies, Auditing: A Journal of Practice and Theory, Vol. 9(1), pp. 29-40.

FAMA, E. (1980): “Agency problems and the theory of the firm, Journal of Political Economy, Vol. 88(20), pp. 288307.

FARGHER, N.; TAYLOR, M. Y SIMON, D. (2001): The demand for auditor reputation across international markets for audit services, The International Journal of Accounting, Vol. 36(4), pp. 407-421.

FINANCIAL REPORTING COUNCIL, (2006): Choice in the UK audit market, Financial Reporting Council Discussion Paper, May, 1-11.

FIRTH, M. (1990): “Auditor reputation: The impact of critical reports issued by government inspectors”, Rand Journal of Economics, 21(3), pp. 374-387.

FIRTH, M. (1997): “The provision of non-audit services and the pricing of audit fees”, Journal of Business, Finance and Accounting Review, Vo. 24(3), pp. 511-525.

FIRTH, M. (2002): “Auditor-Provided Consultancy Services and their Associations with Audit Fees and Audit Opinions", Journal of Business Finance and Accounting, 29, pp. 661-693.

FIRTH, M. Y SMITH, A. (1992): “Selection of auditor firms by companies in new issue market”, Applied Economics, 24, pp. 247-255.

FRANCIS, J. (2004): “What do we know about audit quality?” British Accounting Review, Vol. 36(4), pp. 345-368.

FRANCIS, J. Y WILSON, E. (1988): “Auditor Changes: A Test of Theories Relating to Agency Cost and Auditor Differentiation", The Accounting Review, Vol. 63, No. 4, pp. 663-682.

FRANCIS, J.; RICHELT, K. Y WANG, D. (2005): "The pricing of national and city-specific reputations for industry expertise in the U.S. audit market", The Accounting Review, 80(1), pp. 113-136.

FUERMAN, R.D. (2005): "Differentiating Between Arthur Andersen and the Surviving Big Four on the Basis of Auditor Quality: An Empirical Investigation of the Decision to Criminally Prosecute Arthur Andersen”, SSRN Working Paper.

GAO (2003): Public Accounting Firms: Mandated Study on Consolidation and Competition, (General Accounting Office) retrieved July 3rd, 2003, from http://www.gao.gov.

GARCÍA-BENAU, M. A.; RUIZ BARBADILLO, E. Y VICO MARTÍNEZ, A. (1998): Análisis de la estructura Del mercado de servicios de auditoría en España. VI Premio de investigación Contable "José María Fernández Pirla”. ICAC, Ministerio Economía y Hacienda, Madrid.

GARCÍA-BENAU, M. A.; RUIZ BARBADILLO, E. Y VICO MARTÍNEZ, A. (2000): "Factores que condicionan la elección y el cambio de auditor en la empresa española”, Revista de Contabilidad, vol. 3, No. 6, pp. 49-80.

GARCÍA-BENAU, M. A.; GARRIDO, P.; VICO, A.; MOIZER, P. Y HUMPREY, C. (1999): "La calidad del servicio de auditoría: los auditores vistos por sus clientes", Revista Española de Financiación y Contabilidad, Vol. 28, No. 102, pp. 1005-1042.

GARCÍA-BENAU, M. A.; MOIZER, P.; HUMPHREY, C. Y VICO MARTINEZ, A. (2004): “The Corporate Image of auditors in a developing audit market within the EU: The case of Spain”, European Accounting Review, Vol. 13(3), pp. 561-582.

GIETZMANN, M. Y SEN, P. (2002): "Improving auditor independence through selective mandatory rotation”, International Journal of Auditing, 6, 183-210.

HAY, D. Y DAVIS, D. (2004): "The voluntary choice of an audit of any level of quality, Auditing: A Journal of Practice and Theory, Vol. 23(2), pp. 37-54.

HOGAN, C. E. (1997): "Costs and Benefits of Audit Quality in the IPO Market: A Self-Selection Analysis”, the Accounting Review, Vol. 72, No. 1, p. 67-86.

IRELAND, J. Y LENNOX, C. (2002): “The large audit firm fee Premium: A case of selectivity bias?” Journal of Accounting, Auditing and Finance, Vol. 17(1), pp. 73-91. 
Toscano Moctezuma, J. A., \& Garcia Benau, M. A. (2015). The Election of Big 4 Audit Firms in Mexico and Empirical Analysis (2000-2007). Archives of Business Research, 3(6), 121-137.

JENSEN, M. C. Y MECKLING, H. (1976): “Theory of the firm: Managerial Behaviour, Agency Costs and Ownership Structure", Journal of Financial Economics, October, pp. 305-360.

JOHNSON, W. Y LYS, T. (1990): “The Market for Audit Services-Evidence from Voluntary Auditor Changes”, Journal of Accountancy and Economics, p. 281-308.

JOHNSTONE, K. AND BEDARD, J. (2004): “Audit firm portfolio management decisions”, Journal of Accounting Research, 42, pp. 659-690.

KAPLAN, S. MENON, K. Y WILLIAMS, D. (1990): "The effect of the audit structure on the audit market", Journal of Accounting and Public Policy, pp. 197-215.

KEALEY, B.T.; LEE, H.Y. AND STEIN, M.T. (2007): "The association between audit-firm tenure and audit fees paid to successor auditors: Evidence from Arthur Andersen", Auditing: A journal of Practice \& Theory, 26(2), pp. 95116.

KNAPP, M. (1991): "Factors that audit comitte members use surrogates for audit quality". Auditing: A Journal of Practice \& Theory, Vol. 10, and No. 1.

KRISHNAMURTHY, S.; ZHOW, J. Y ZHOW, N. (2002): “Auditor Reputation, Auditor Independence, and the Stock Market Reaction to Andersen's Clients", SSRN Working Paper.

LAI, K. Y YIM, A. (2002): “Non-audit services and Big Five auditor independence: Evidence from audit pricing and audit opinion of initial engagement. Working paper, SSRN

LANDSMAN, W.R.; NELSON, K.K. Y ROUNTREE, B. (2008): “Auditor switches in the pre and post-Enron eras: risk or realignment?" Accounting Review, forthcoming.

MARTEN, K. U.; MOIZER, P. Y SCHMÖLLER, P. (1998): “The Image of Audit Firms-Empirical Evidence from the German audit Market", paper presented at the XXI Congress of the European Accounting Association, Ambers.

MENON, K. Y WILLIAMS, D. (1991): “Auditor Credibility and Initial Public Offerings”, the Accounting Review, No. 2, p. 313.

MENON, K. Y WILLIAMS, D. (2001): “Long-term in Audit Fees”, Auditing: A Journal of Practice and Theory, vol. 20, no. 1, pp. 115-130.

MOCK, T. Y SAMET, M. (1982): “A Multi-Attribute Model, Proceeding of the VI University of Kansas Audit Symposium.

MOIZER, P. (1997): “Auditor reputation: The international empirical evidence”, International Journal of Auditing, Vol. 1(1), pp. 61-74.

MOIZER, P.; GARCIA BENAU, M. A.; HUMPHREY, C. Y VICO, A. (1998): "Finding the Ideal Auditor: The Images of Audit Firms held by Spanish Financial Directors", Accounting Auditing and Accountability Journal

MONTERREY, J. Y SÁNCHEZ A. (2008): “Gobierno corporativo, Conflictos de Agencia, y Elección de Auditor”, Revista Española de Financiación y Contabilidad, Vol. XXXVII, No. 137, pp. 113-156.

NICHOLS, D. Y SMITH, D. (1983): “Auditor credibility and auditor changes”, Journal of Accounting Research, Vol. 21(2), pp. 534-544.

ONDER, T.; AKSU, M. Y BALCI, Y. (2004): “Auditor Selection in the Istanbul Stock Exchange”, Paper presented at the 27th annual Congress of the European Accounting Association (EAA), Prague Czech Republic.

PALMROSE, Z. (1984): “The demand for quality-differentiated audit services in an agency cost setting: An Empirical Investigation”, Auditing Research Symposium (University of Illinois), pp. 229-252.

PALMROSE, Z. (1988): “An analysis of auditor ligitation and audit service quality. The Accounting Review, January, pp. 55-73.

PIOT CH. (2001): “Agency Costs and Audit Quality: Evidence from France”, the European Accounting Review, vol. $10(3)$, pp. 461-499.

PITTMAN, J. Y FORTIN, S. (2004): “Auditor choice and the cost of debt capital for newly public firms”, Journal of Accounting and Economics, 37, pp. 113-136. 
PONG, C. Y WHITTINGTON, G. (1994): “The Determinants of Audit Fees: Some Empirical Models”, Journal of Business Finance \& Accounting, vol. 21, no. 8, pp. 1071-1045.

SCHROEDER, M. S.; SOLOMON, I.; Y VICKREY, D. (1986): “Audit Quality: The Perceptions of Audit-Committee Chairpersons and Audit Partners”, Auditing: A Journal of Practice and Theory, vol. 5, no. 2, pp. 86-94.

SHLEIFER, A. Y VISHNY, R. (1986): "Large shareholders and corporate control, Journal of Political Economy, vol. 94, pp. 461-488.

SHROEDER, M. S.; SOLOMON, I. Y VICKREY, D. (1986): “Audit Quality: The Perceptions of Audit-Committee Chairpersons and Audit Partners", Auditing: A Journal of Practice and Theory, Vol. 5, No. 2, pp. 86-94.

SIMUNIC, D. A. Y STEIN, M. (1987): "Product Differentiation in Auditing: A Study of Auditor Choice in the Market for New Issues", Canadian Certified General Accounts Research Foundation, Monograph 13.

SUTTON, S. Y LAMPE, J. (1990): “Formulating a Process Measurement System for Audit Quality”, In Proceedings of the 1990 University of South California Audit Judyment Symposium.

STEIN, M.; SIMUNIC, D. Y O'KEEFE, T. (1994): “Industry differences in the production of audit services, Auditing: A Journal of Practice and Theory, Vol. 13 (Supplement), pp. 128-142.

TEOH, S. Y WONG, T. (1993): "Perceived auditor quality and the earnings response coefficient, The Accounting Review, Vol. 68(2), pp. 346-366.

ThORNTON, D. Y MOORE, G. (2006): “Auditor Choice and Audit Fee Determinants”, Journal of Business Finance \& Accounting, Volume 20(3), pp. 333-349.

TIESENHAUSEN, V.F. (2004): “Big Four`s dominance shows no let up amid calls for scrutiny”, Financial Times, 6 January 2004, page. 22.

VAFEAS, N. (1999): “Board meeting frequency and firm performance”, Journal of Financial Economics, 53, pp. 113142.

WATTS, R. Y ZIMMERMAN, J. (1983): “Agency problems, auditing, and the theory of the firm: Some evidence”, Journal of Law and Economics, Vol. 26(3), pp. 613-633.

WHISENANT, J. Y SANKARAGURUSWAMY, S. (2000): “Evidence on the auditor and client relationship: What can be learned from reasons reported by managers for changing auditors?" Working paper SSRN

WILLEKENS, M.; BAUWHEDE, H.V. Y GAEREMYNCK, A. (2004): "Voluntary audit committee formation and practices among Belgian listed companies”. International Journal of Auditing, 8(3), pp. 207-222.

WILLIAMS, D. D. (1988): “The Potential Determinants of Auditor Change”, Journal of Business, Finance and Accounting, 15(2), pp. 243-261.

ZEFF S. Y FOSSUM, R. (1967): “An analysis of Large Audit Clients”, The Accounting Review, Vol. 42, No. 2. April, pp. 298-320. 